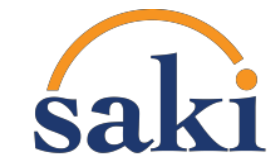

Studi Akuntansi \& Keuangan Indonesia

\title{
PENGARUH KEPEMILIKAN INSTITUSIONAL TERHADAP STRUKTUR MODAL DAN NILAI PERUSAHAAN DI INDONESIA
}

\author{
Andriyani Surjadi, Irene Vania, Wijantini, Retno Yuliati \\ Sekolah Bisnis dan Ekonomi - Universitas Prasetiya Mulya \\ BSD City Kavling Edutown I.1, Jl. BSD Raya Utama, BS D City, Tangerang 15339
}

Keywor ds :

Agency Theory, Capital Structure, Firm Value, Institutional Ownership, Pecking Order Theory

Kata Kunci:

Teori agensi, stuktur modal, nilai perusahaan, kepemilikan institusional, teori pecking Order

Corresponding Author: andriyani.surjadi@gmail.com

\begin{abstract}
This study aimed to investigate the influence of institutional ownership on firm value and capital structure, also the influence of capital structure on firm value. This study contributes as a confirmation of the prior studies' findings. Capital structure is measured with long-term debt to equity and firm value is measured with Tobin's Q. Sample for this study includes 160 manufacturing companies listed on Bursa Efek Indonesia (BEI) in 20062015. The regression model used is Pooled Ordinary Least Squares (OLS). The findings of this study indicate that institutional ownership positively influences firm value by practicing effective monitoring which reduces agency problem, consistent with Jafarinejad (2015) and Lins (2003). Institutional ownership negatively influences capital structure assessed through pecking order theory, caused by the decreased information gap between shareholder and management and the institutional ownership's monitoring as a subtitute of debt and in line with Michaely and Vincent (2013) and Chaganti and Damanpour (1991). Capital structure positively influences firm value as debt has a controlling role in the company will reduce agency problem thus raising firm value, consistent with agency theory developed by Jensen and Meckling (1976). The result is consistent with Hasbi (2015) and Zeitun and Tian (2007).
\end{abstract}

\section{SARIPATI}

Penelitian ini bertujuan untuk mengetahui pengaruh kepemilikan institusional terhadap nilai perusahaan dan struktur modal, serta pengaruh struktur modal terhadap nilai perusahaan. Kontribusi penelitian ini untuk penelitian di Indonesia adalah sebagai konfirmasi hasil penelitian sebelumnya. Nilai perusahaan diukur dengan proksi Tobin's Q dan struktur modal diukur dengan proksi long-term debt to equity. Metode pemilihan sampel penelitian menggunakan metode purposive sampling, sehingga tercapai sampel penelitian sebanyak 160 perusahaan manufaktur yang terdaftar di Bursa Efek Indonesia pada tahun 2006-2015. Data sampel diolah menggunakan metode regresi Pooled Ordinary Least Squares (OLS). Hasil penelitian menunjukkan bahwa kepemilikan institusional berpengaruh positif terhadap nilai perusahaan karena adanya monitoring yang efektif sehingga mengurangi konflik agensi sesuai penelitian Jafarinejad (2015) dan Lins (2003). Kepemilikan institusional mempengaruhi struktur modal secara negatif jika dikaji lewat teori pecking order karena mengurangnya information gap antara manajemen dan pemegang saham eksternal serta peran investor institusional sebagai substitusi kontrol dari utang jika dikaji dengan teori agensi, konsisten dengan penelitian Michaely dan Vincent (2013) dan Chaganti dan Damanpour (1991). Struktur modal berpengaruh positif terhadap nilai perusahaan karena utang bertindak sebagai wujud kontrol yang akhirnya akan mengurangi konflik agensi sesuai dengan teori agensi menurut Jensen dan Meckling (1976). Hal ini konsisten dengan hasil penelitian Hasbi (2015) dan Zeitun dan Tian (2007). 


\section{Pendahuluan}

Pasar modal adalah salah satu faktor yang mempengaruhi ekonomi secara nasional dengan menggerakan sumber daya finansial yang dimiliki masyarakat dan menyalurkan kepada perusahaanperusahaan sebagai modal yang dapat membantu pertumbuhan ekonomi negara. Di Indonesia, Bursa Efek Indonesia (BEI) berperan sebagai pasar modal. Pada tahun 2016, jumlah investor meningkat 23,47\% menjadi 535.994 single investor identificator (SID), investor aktif meningkat 21,35\% menjadi 187.268 SID, serta rasio investor aktif meningkat dari 1,14\% menjadi 14,72\% (Laporan Operasional Bursa Efek Indonesia, 2016). Salah satu penggerak bagi investor lain untuk aktif trading dalam pasar modal adalah kehadiran investor institusional (Setianto, 2016), yaitu pemegang saham yang berupa perusahaan asuransi, perusahaan investasi, lembaga dana pensiun, dan lembaga keuangan lainnya (Gillian dan Starks, 2000; Tarjo, 2008).

Kehadiran investor institusional tersebut menimbulkan pertanyaan, apakah investor institusional tersebut akan mempengaruhi perusahaan-perusahaan dimana mereka berinvestasi. Hal ini mengingat investor institusional menempati posisi sebagai principle dalam perusahaan dan manajemen adalah sebagai agen. Terjadi pemisahan antara kontrol dan kuasa, yang dapat menjadi pemicu agency problem, seperti yang disebutkan dalam teori agensi (Jensen dan Meckling, 1976).

Agency problem dapat menimbulkan agency cost saat manajemen bertindak tidak sesuai kehendak pemegang saham dan akan mempengaruhi nilai perusahaan. Namun agency problem ini dapat diatasi dengan monitoring yang baik. Investor institusional cenderung memiliki porsi kepemilikan yang besar dalam perusahaan dan memiliki incentive kuat serta skill yang lebih baik dalam melakukan pengawasan (Grossman dan Hart, 1986; Shleifer and Vishny, 1986; Attig, Cleary, El Ghoul, \& Guedhami, 2012). Kontrol yang dilakukan investor institusional bersifat efisien dan tepat (Berger dan Patti, 2006; Hillman dan Dalziel, 2003) yang bertujuan untuk menjaga kondisi investasi nya dari keputusan manajemen yang dapat mengurangi kemakmuran pemegang saham (Shleifer \& Vishny, 1986; Bhojraj dan Sengupta, 2003).

Keberadaan investor institusional dapat memitigasi dan mengatasi agency problem (Attig et al., 2012; Jafarine jad, Jory, \& Ngo, 2015) yang secara langsung juga mempengaruhi nilai perusahaan. 
Hal ini disebabkan nilai perusahaan maksimal tercapai saat konflik antara agen dan principle dapat diminimumkan, seperti hasil penelitian Lins (2003), Navissi and Naiker (2006), Jafarinejad et al. (2015), dan McConnell dan Servaes (1990).

Bentuk pengawasan serupa dapat ditemukan dalam utang (Jensen, 1986). Utang adalah salah satu wujud kontrol internal perusahaan (Crutchley, Jensen, Jahera, \& Raymond, 1999), sedangkan investor institusional merupakan pihak yang berperan secara signifikan sebagai kontrol eksternal lewat pasar modal (Agrawal dan Mandelker, 1990). Utang memaksa manajemen untuk berkomitmen terhadap pembayaran utang (Jensen, 1986). Manajemen akan dihadapkan pada ancaman likuidasi jika tidak memenuhi pembayaran utang (Grossman dan Hart, 1982). Dengan begitu, nilai perusahaan akan mencapai titik maksimal dengan kontrol dari utang, serta struktur modal berpengaruh terhadap nilai perusahaan.

Penelitian hubungan variabel independen kepemilikan institusional terhadap kedua variabel nilai perusahaan dan struktur modal pernah diteliti sebelumnya oleh peneliti-peneliti di berbagai negara. Hubungan antara kepemilikan institusional dengan nilai perusahaan telah diteliti oleh Lins (2003), Chaganti dan Damanpour (1991), Han dan Suk (1992), Jafarinejad et al. (2015), dan McCornnell dan Servaes (1990) yang menyimpulkan bahwa adanya pengaruh positif kepemilikan institusional terhadap nilai perusahaan. Namun penelitian yang dilakukan oleh Morck, Nakamura, \& Shivdasani (2000), Wei, Xie, \& Zhang (2005) dan Bhatthacharya dan Graham (2009) menyatakan adanya pengaruh negatif antara kedua variabel. Di sisi lain, tidak ada bukti yang kuat atas adanya pengaruh signifikan antara kepemilikan institusional terhadap nilai dan kinerja perusahaan tersebut menurut penelitian yang dilakukan Gregory dan Wang (2009) dan Al-Saidi dan Al-Shammari (2015).

Hubungan antara kepemilikan institusional dan struktur modal telah diteliti oleh Pirzada, Mustapha, \& Wickramasinghe (2015) pada perusahaan yang terdaftar di Bursa Malaysia, dimana penelitian tersebut menyimpulkan bahwa tidak ada pengaruh signifikan antara kedua variabel tesebut. Namun, hasil dari penelitian oleh Chaganti dan Damanpour (1991), Al-Najjar dan Taylor (2008), dan Michaely and Vincent (2013) menunjukkan bahwa adanya pengaruh signifikan, yaitu pengaruh negatif, antara kepemilikan institusional dengan struktur modal perusahaan. Penelitian yang dilakukan oleh Firth (1995) dan Hammerström dan Jersov (2014) menyatakan bahwa ada pengaruh positif 
kepemilikan institusional terhadap struktur modal.

Hubungan antara struktur modal dan nilai perusahaan dapat dilihat dalam penelitian Margaritis dan Psillaki (2010), Zeitun dan Tian (2014), dan Hasbi (2015) yang menunjukkan adanya pengaruh pos itif antara kedua variabel. Namun, penelitian Soumadi dan dan Hayajneh (2012) dan Vo dan Ellis (2016) menunjukkan hasil pengaruh negatif.

Penelitian ini dimotivasi adanya inkonsistensi hasil penelitian-penelitian sebelumnya yang menjadikan topik penelitian ini menarik untuk ditinjau ulang. Selain itu, penelitian-penelitian terdahulu membuktikan bahwa perbedaan lokasi pengambilan sampel dapat mempengaruhi hasil penelitian karena memiliki kondisi makro dan regulasi yang berbeda setiap negara (Bhattacharya dan Graham, 2009). Penelitian ini memberikan kontribusi antara lain sebagai konfirmasi atas hasil penelitian terdahulu di Indonesia. Berangkat dari motivasi dan celah penelitian, rumusan masalah dari penelitian ini ialah

1. Apakah kepemilikan institusional berpengaruh positif terhadap nilai perusahaan?

2. Apakah kepemilikan institusional berpengaruh negatif terhadap struktur modal perusahaan?

3. Apakah struktur modal berpengaruh positif terhadap nilai perusahaan?

\section{Landasan Teori dan Pengembangan Hipotesis}

Teori Agensi

Hubungan agensi didefinisikan oleh Jensen dan Meckling (1976) sebagai hubungan dimana satu atau sekelompok orang yang berperan sebagai principle melibatkan satu atau sekelompok orang sebagai agen untuk menjadi perwakilan principle dalam mewujudkan kepentingannya, antara lain dengan memberikan wewenang dalam pengambilan keputusan. Di dalam hubungan agensi, agen tidak akan selalu bertindak sesuai dengan kepentingan principle atau disebut juga dengan perbedaan kepentingan. Hal ini disebabkan adanya pemisahan kuasa dan kontrol. Terdapat 3 macam hubungan agensi

1. Hubungan antara pemegang saham dan manajemen, dimana pemegang saham merupakan principle dan manajemen menjadi agen. 
2. Hubungan antara pemegang saham non-controlling dan pemegang saham controlling, dimana pemegang saham non-controlling menjadi principle sedangkan pemegang saham controlling menjadi agen.

3. Hubungan antara stakeholders seperti kreditur dan perusahaan, dimana stakeholders menjadi principle sedangkan perusahaan menjadi agen.

Teori agensi terfokus pada hubungan principle dan agen dimana manajemen cenderung ingin mendahulukan kepentingannya seperti insentif, sedangkan pemegang saham juga memiliki kepentingannya sendiri, salah satunya memaksimalkan nilai perusahaan. Tindakan yang dilakukan manajemen ini dapat mempengaruhi nilai perusahaan secara negatif, seperti menjalankan proyekproyek yang tidak menguntungkan bagi perusahaan. Saat manajemen menjalankan upaya mewujudkan kepentingan pribadinya, agency cost akan timbul sebagai akibat dari agency problem.

Agency cost dapat berupa biaya untuk mengkontrol manajemen (biaya kontrol), biaya bonding untuk memastikan bahwa agen akan terus berjalan sepihak dengan principle, ataupun the residual loss yang merupakan nilai uang yang menjadi kerugian bagi principle saat agen membuat keputusan yang tidak memaksimalkan kesejahteraan principle.

\section{Pecking Order Theory}

Teori pecking order menyatakan bahwa perusahaan tidak memiliki target struktur modal. Myers dan Majluf (1984) menyatakan bahwa perusahaan cenderung untuk memilih pendanaan internal (saldo laba, kas, dan aset lancar) sebagai prioritas, lalu memilih utang diband ingkan dengan penerbitan saham apabila pendanaan eksternal diperlukan. Teori ini didasari adanya asymmetry information antara manajemen dan investor. Manajemen mengetahui lebih banyak mengenai perusahaannya, dari segi risiko, kinerja, dan kondisi secara keseluruhan, dan hal ini disadari oleh investor dan manajemen.

Asymmetry information menimbulkan information cost, yaitu biaya untuk mengedukasi dan menyediakan informasi bagi investor. Investor membutuhkan informasi yang cukup sebelum memutuskan untuk menginvestasikan dananya pada perusahaan. Hal ini yang menyebabkan manajemen lebih memilih utang dibandingkan pendanaan dari investor, karena utang membutuhkan 
information cost lebih rendah.

Untuk mengurangi asymmetry information yang terjadi, manajemen perlu untuk menyediakan detail yang terverifikasi mengenai keadaan perusahaan yang sebenarnya (Myers dan Majluf, 1984). Namun informasi yang telah disediakan tersebut tetap dapat menimbulkan asymmetry information bagi investor yang tidak memiliki pengetahuan bisnis yang setara dengan manajemen. Hubungan antara investor dan manajemen secara alami akan menimbulkan asymmetry information. Hal ini yang menyebabkan perusahaan cenderung memilih pendanaan internal dibandingkan pendanaan eksternal karena pendanaan internal memerlukan information cost yang lebih sedikit. Menambah jumlah saham beredar juga berkemungkinan besar menjatuhkan harga saham. Alasan ini mendukung mengapa perusahaan cenderung memilih pendanaan eksternal dalam bentuk utang.

\section{Kepemilikan Institusional}

Kepemilikan institusional didefinisikan oleh Gillan dan Starks (2008) dan Tarjo (2008) sebagai saham perusahaan yang dimiliki oleh institusi atau lembaga seperti perusahaan asuransi, bank, perusahaan investasi dan kepemilikan institusi lain ataupun lembaga keuangan lainnya. Investor institusional cenderung memegang proporsi besar dalam struktur kepemilikan saham perusahaan (Gillan dan Starks, 2008), didukung oleh Tarjo (2008) yang menyatakan bahwa kepemilikan institusional merupakan investor besar dengan pendanaan yang besar pula.

Kepemilikan yang besar ini dapat diartikan bahwa investor institusional memiliki hak suara dan kontrol atas manajemen. Investor institusional yang cenderung lebih berinisiatif untuk ikut memantau pengambilan keputusan yang dilakukan oleh manajemen guna memastikan perusahaan tempatnya berinvestasi aman (Shleifer dan Vishney, 1986).

Selain berinisiatif lebih, investor institusional juga lebih handal dalam monitoring dibanding pemegang saham minoritas (Grossman dan Hart, 1980). Hal ini disebabkan investor institusional menikmati lebih banyak keuntungan hasil monitoringnya dan memiliki hak suara untuk menentang keputusan manajemen yang merugikan (Bhojraj \& Sengupta, 2003). Penelitian Sundaramurthy, Rhoades, \& Rechner (2005) menambahkan bahwa investor institusional biasanya memiliki wakil yang duduk dalam jajaran direksi perusahaan untuk melakukan pengawasan langsung. Oleh sebab itu, dapat 
disimpulkan bahwa investor institusional melakukan kontrol langsung kepada kinerja perusahaan agar manajemen tidak melakukan tindakan manipulatif dan menekan konflik agensi di perusahaan.

\section{Pengembangan Hipotesis}

\section{Kepemilikan Institusional terhadap Nilai Perusahaan}

Struktur kepemilikan akan mempengaruhi jalannya perusahaan, didukung pernyataan Chung dan Zhang (2011) bahwa kepemilikan institusional yang tinggi cenderung memicu corporate governance yang lebih berkualitas. Navissi and Naiker (2006) juga menemukan bahwa kepemilikan saham dari investor institusional pada proporsi tertentu memiliki pengaruh posit if kepada perusahaan.

Penelitian yang dilakukan oleh Al-Najjar (2015) dengan sampel perusahaan di Jordania, Lee (2008) di Korea Selatan, Al-Saidi dan Al-Shammari (2015) dengan sampel perusahaan di Kuwait, dan Gregory dan Wang (2009) dengan sampel perusahaan di Inggris menghasilkan bahwa tidak adanya pengaruh antara kepemilikan institusional dengan nilai dan kinerja perusahaan. Hal ini disebabkan oleh faktor kondisi makro di negara masing-masing.

Sebaliknya, penelitian Penelitian Bhatthacharya dan Graham (2009) menemukan hubungan signifikan antar 2 jenis investor institus ional (pressure-sensitive dan pressure-resistant), dimana hasil dari penelitian ini menunjukkan bahwa kedua jenis investor institusional memiliki pengaruh negatif terhadap Tobin's Q. Hasil penelitian Wei et al. (2015) juga menemukan adanya pengaruh negatif antara kedua variabel karena badan institusional di Cina dimiliki sepenuhnya atau sebagian oleh pemerintah. Masyarakat beranggapan bahwa pemerintah Cina tidak menjalankan monitoring atas manajemen dengan mekanisme yang tepat.

Mayoritas dari hasil penelitian-penelitian terdahulu menunjukkan hasil kepemilikan institusional berpengaruh pos itif terhadap nilai perusahaan (Chaganti dan Damanpour, 1991; Han dan Suk, 1992; McConnell dan Servaes, 1990; Lin, 2003; Jafarinejad et al., 2015). Hal ini disebabkan pemilik institusional aktif dalam peran pengawasan manajemen dan mencegah adanya sikap berkubu dari manajemen sehingga hubungan antara kedua variabel adalah positif. Kontrol yang dilaksanakan pemegang saham eksternal merupakan suatu governance sehingga sikap manajemen yang membangkang tidak akan menjatuhkan nilai perusahaan. Sesuai teori agensi, perbedaan kepentingan antara principle dan agen menimbulkan agency cost yang dapat mempengaruhi nilai perusahaan secara negatif. Investor institusional dikatakan melakukan pengawasan terhadap perusahaan serta 
memiliki insentif dan efisiensi yang lebih tinggi dalam memonitor perusahaan dan memitigasi agency problem (Attig et al., 2012). Investor institusional bahkan dapat mengurangi praktik agency problem (Gregory dan Wang, 2009) dan mengurangi agency conflict (Jafarinejad et al., 2015). Dengan demikian, dapat dirumuskan hipotesis:

H1. Terdapat hubungan positif antara Kepemilikan Institusional dengan Nilai Perusahaan

\section{Kepemilikan Institusional terhadap Struktur Modal}

Investor institusional memiliki kepemilikan dengan porsi besar, memiliki incentive yang kuat dan kemampuan monitoring yang lebih baik dari pemegang saham minoritas (Grossman dan Hart, 1980). Saat investor institusional berperan sebagai kontrol secara eksternal, terdapat kontrol serupa yang bersifat internal yaitu utang (Agrawal dan Mandelker, 1990; Crutchley et al., 1999).

Penelitian yang dilakukan oleh Firth (1995) dan Hammerström dan Jersov (2014). menunjukkan bahwa terdapat pengaruh positif antara kepemilikan saham institusional dan rasio utang jangka panjang karena pemegang saham institusional menginginkan perusahaan dengan profitabilitas tinggi, sama seperti pemegang saham lainnya. Dengan begitu, pemilik institusional menjadi hambatan bagi manajemen yang cenderung menginginkan utang lebih sedikit. Selain penelitianpenelitian terdahulu yang menghasilkan pengaruh positif, penelitian Ashrafi (2015) menunjukkan bahwa institusi yang sensitif terhadap tekanan memiliki pengaruh positif saat memiliki komposisi kepemilikan institusional yang rendah, negatif saat mencapai titik tertentu, kemudian positif saat kepemilikan institusional tergolong tinggi. Sebaliknya, institusi yang insensitif terhadap tekanan memiliki pengaruh negatif saat kepemilikan rendah, positif pada titik tertentu, kemudian negatif saat kepemilikan tinggi dan memiliki pengaruh kubikal. Sebaliknya, penelitian Pirzada et al., (2015) yang dilakukan atas perusahaan Malaysia menunjukkan hasil bahwa tidak ada pengaruh kepemilikan institusional terhadap rasio utang jangka panjang. Hal ini dikarenakan bahwa perusahaan Malaysia cenderung mendanai perusahaannya dengan modal internal.

Penelitian mengenai hubungan kepemilikan institusional dengan struktur modal dilakukan oleh Chaganti dan Damanpour (1991) dan Michaely dan Vincent (2013) dengan hasil penelitian ini menunjukkan pengaruh negatif karena perusahaan dengan komposisi saham lebih besar dipegang oleh 
investor institusional secara relatif memiliki rasio utang yang rendah.

Meninjau dari penelitian-penelitian terdahulu, penulis menyimpulkan bahwa kepemilikan institusional memiliki pengaruh negatif terhadap struktur modal perusahaan. Utang yang merupakan komponen struktur modal memaksa perusahaan untuk melakukan pembayaran secara berkala (Jensen, 1986) yang menunjukkan adanya kontrol. Selain itu, utang memang merupakan salah satu bentuk kontrol internal (Crutchley et al., 1999). Kontrol ini serupa dengan kontrol dari pemilik institusional, namun bersifat eksternal (Agrawal dan Mandelker, 1999), sehingga keduanya saling substitusi. Jika ditinjau dari teori pecking order, pendanaan secara utang menjadi prioritas dibandingkan pendanaan secara saham karena adanya asymmetry information (Myers dan Majluf, 1984). Peran investor institusional akan mengurangi asymmetry information yang ada karena informasi yang diperoleh investor institusional terefleksi dalam pola trading nya (Bushee dan Godman, 2007). Hal ini menyebabkan information cost menurun dan dapat memicu penurunan proporsi utang dalam perusahaan yang dimiliki pemilik institusional yang tinggi. Oleh sebab itu, hipotesis pada penelitian ini adalah:

H2. Terdapat hubungan negatif antara kepemilikan institusional dengan struktur modal perusahaan

\section{Struktur Modal terhadap Nilai Perusahaan}

Struktur modal merupakan proporsi pendanaan perusahaan yang terbentuk dari seberapa besar pendanaan dari utang maupun dari modal. Utang dapat menjadi subsitusi atas kontrol yang dilakukan oleh principle (Jensen, 1986). Dengan adanya peran kontrol dari utang, maka utang memiliki pengaruh terhadap nilai perusahaan dengan meminimalisasi agency problem serta agency cost.

Penelitian Vo dan Ellis (2016) dan Soumadi dan Hayajneh (2012) menunjukan hasil pengaruh negatif antara tingkat utang dan nilai perusahaan. Hal ini disebabkan investor cenderung mengalami kerugian saat berinvestasi di perusahaan dengan rasio utang yang tinggi karena rendahnya pengembalian. Selain itu, utang yang berlebihan dapat meningkatkan risiko pailit yang menghapuskan keuntungan secara pajak dari pendanaan utang sehingga menurunkan Tobin's Q.

Berlawanan dengan penelitian-penelitian tersebut, Margaritis dan Psillaki (2010) menunjukkan bahwa kedua variabel memiliki pengaruh positif karena rasio utang yang tinggi 
meningkatkan efisiensi perusahaan. Penelitian lainnya adalah penelitian Zeitun dan Tian (2014) yang meninjau hubungan antara short term debt-to-total asset terhadap Tobin's Q dengan hasil struktur modal berpengaruh positif terhadap Tobin's Q karena sesuai penelitian Myers (1977) bahwa perusahaan dengan porsi utang jangka pendek yang tinggi menunjukan performa yang lebih baik. Studi kasus Hasbi (2015) pada sebuah perusahaan microfinance juga menemukan adanya pengaruh positif antara struktur modal dan nilai perusahaan.

Penelitian-penelitian sebelumnya mayoritas menunjukan hasil pengaruh positif, termasuk penelitian Hasbi (2015) yang dilakukan di Indonesia. Dari teori agensi, dapat diketahui bahwa kontrol dapat mengatasi agency problem (Jensen dan Meckling, 1976). Utang bahkan dapat memicu kontrol dari kreditur yang juga dapat mengatasi agency problem dan agency cost yang terkait (Agrawal and Knoeber, 1996). Dari sisi free cash flow, manajemen akan membatasi penggunaan free cash flow yang tersedia untuk kepentingan lainnya yang tidak menguntungkan perusahaan agar dapat melunasi utang (Jensen, 1986). Dengan begitu, utang dapat menjadi salah satu bentuk corporate governance (Mulyani Singh, \& Mishra, 2016), dimana hal tersebut dapat meningkatkan nilai perusahaan (Klapper dan Love, 2004; Cheung, Connelly, Limpaphayom, \& Zhou, 2007). Oleh sebab itu, hipotesis penelitian ini adalah:

H3.Terdapat hubungan positif antara Struktur Modal dengan Nilai Perusahaan

\section{Metode Penelitian}

\section{Data dan Sampel}

Populasi dari penelitian ini adalah perusahaan Indonesia yang tercatat dalam Bursa Efek Indonesia (BEI) pada periode tahun 2006-2015 yang bergerak di bidang manufaktur, dengan alasan industri manufaktur memiliki sensitivitas yang tinggi terhadap kejadian internal maupun eksternal perusahaan (Hariati dan Rihatiningtyas, 2015). Pengambilan sampel dilakukan dengan metode purposive sampling.

Data-data pada penelitian ini bersumber dari laporan tahunan yang dipublikasikan perusahaan manufaktur di Indonesia, platform data keuangan terpercaya yaitu Capital IQ, website perusahaan, serta website BEI yaitu www.idx.co.id. Perusahaan dengan ekuitas negatif atau defisiensi modal 
dikeluarkan karena hal tersebut menunjukan perusahaan tidak memiliki nilai market capitalization.

Proksi nilai perusahaan yang digunakan penelitian ini adalah Tobin's Q, sehingga market capitalization diperlukan untuk mengkalkulasi nilai Tobin's Q.

\section{Model Penelitian}

Penelitian ini menggunakan metode regresi dengan data panel yang diolah dalam program Stata versi 13.0. Pengolahan data menggunakan model Pooled Ordinary Least Square (OLS). Berikut merupakan regresi penelitian untuk ketiga hipotesis yang diajukan dalam penelitian ini

Model 1 untuk menguji hipotesis 1 dan 3

$\mathrm{Q}_{\mathrm{it}}=\alpha+\beta_{1} \mathrm{IO}_{\mathrm{it}}+\beta_{2} \mathrm{LEV}_{\mathrm{it}}+\beta_{3} \mathrm{SIZE}_{\mathrm{it}}+\beta_{4} \mathrm{ROA}_{\mathrm{it}}+\beta_{5} \mathrm{CAPEX}_{\mathrm{it}}+\beta_{6} \mathrm{BIG}_{\mathrm{it}}+\beta_{7} \mathrm{PER}_{\mathrm{it}}+\mathrm{e} \ldots \ldots .(1)$

Model 2 untuk menguji hipotesis 2

$$
\begin{aligned}
\mathrm{LEV}_{\mathrm{it}}= & \alpha+\beta_{1} \mathrm{IO}_{\mathrm{it}}+\beta_{2} \mathrm{SIZE}_{\mathrm{it}}+\beta_{3} \mathrm{LIQ}_{\mathrm{it}}+\beta_{4} \mathrm{TANG}_{\mathrm{it}}+\beta_{5} \mathrm{AGE}_{\mathrm{it}}+\beta_{6} \mathrm{RISK}_{\mathrm{it}}+\beta_{7} \mathrm{CASHRATIO}_{\mathrm{it}} \\
& +\beta_{8} \mathrm{NDTS}_{\mathrm{it}}+\beta_{9} \mathrm{GRASSET}_{\mathrm{it}}+\mathrm{e} . \ldots . .(2)
\end{aligned}
$$

\begin{tabular}{|c|c|}
\hline $\mathrm{LEV}_{\text {it }}$ & : Struktur modal (Rasio Long term debt-to-Equity) pada tahun $\mathrm{t}$ \\
\hline $\mathrm{IO}_{\text {it }}$ & : Persentase kepemilikan institusional pada tahun $\mathrm{t}$ \\
\hline $\mathrm{Q}_{\mathrm{it}}$ & : Nilai perusahaan $(\mathrm{Q})$ pada tahun $\mathrm{t}$ \\
\hline $\mathrm{SIZE}_{\mathrm{it}}$ & : Ukuran perusahaan pada tahun $\mathrm{t}$ \\
\hline $\mathrm{AGE}_{\mathrm{it}}$ & : Umur perusahaan sampai dengan tahun $\mathrm{t}$ \\
\hline GRASSET $_{\text {it }}$ & : Pertumbuhan total aset pada tahun $\mathrm{t}$ \\
\hline $\mathrm{ROA}_{\mathrm{it}}$ & : Profitabilitas (Return on Asset) pada tahun $\mathrm{t}$ \\
\hline TANG $_{\text {it }}$ & : Tangibility pada tahun $\mathrm{t}$ \\
\hline $\mathrm{BIG}_{\mathrm{it}}$ & : Dummy auditor BIG 4 pada tahun $\mathrm{t}$ \\
\hline RISK $_{\text {it }}$ & : Risiko bisnis pada tahun $\mathrm{t}$ \\
\hline $\mathrm{CAPEX}_{\text {it }}$ & : Peluang investasi pada tahun $\mathrm{t}$ \\
\hline $\mathrm{PER}_{\text {it }}$ & : Price-earning-ratio pada tahun $\mathrm{t}$ \\
\hline $\mathrm{LIQ}_{\text {it }}$ & : Likuiditas pada tahun $\mathrm{t}$ \\
\hline CASHRATIO $_{\text {it }}$ & : Rasio kas pada tahun $\mathrm{t}$ \\
\hline NDTS $_{\text {it }}$ & : Keuntungan pajak bukan utang pada tahun $\mathrm{t}$ \\
\hline$e_{t}$ & : error \\
\hline $\mathrm{i}$ & : Jumlah perusahaan \\
\hline $\mathrm{t}$ & : Tahun observasi \\
\hline
\end{tabular}

Keterangan:

\section{Operasionalisasi Variabel}

Variabel penelitian ini terdiri dari kepemilikan institusional, struktur kepemilikan, dan nilai perusahaan. Adapun operasionalisasi variabel penelitian dapat dideskripsikan pada tabel 3.1. 
Tabel 3.1 - Ope rasionalisasi Variabel

\begin{tabular}{|c|c|c|}
\hline Variabel & Proksi & Formula \\
\hline $\begin{array}{l}\text { Kepemilikan } \\
\text { Institusional (IO) }\end{array}$ & $\begin{array}{l}\text { Proporsi saham yang dimiliki } \\
\text { investor institusional }\end{array}$ & $\frac{\text { Jumlah saham yang dimiliki investor institusional }}{\text { Jumlah saham beredar }} \times 100 \%$ \\
\hline $\begin{array}{l}\text { Struktur Modal } \\
\text { (LEV) }\end{array}$ & Long-term Debt to Equity & Long term debt $\div$ Total equity \\
\hline $\begin{array}{l}\text { Nilai Perusahaan } \\
\text { (Q) }\end{array}$ & Tobin's Q & $\frac{\text { Equity market value }+ \text { Total debt value }}{\text { Total asset value }}$ \\
\hline $\begin{array}{l}\text { Ukuran Perusahaan } \\
\text { (SIZE) }\end{array}$ & Natural Logaritma Total Aset & In Total Assets \\
\hline Likuiditas (LIQ) & Quick Ratio & $\frac{\text { Current assets - Inventory }}{\text { Liabilities }}$ \\
\hline $\begin{array}{l}\text { Tangibility } \\
\text { (TANG) }\end{array}$ & $\begin{array}{l}\text { Proporsi aset tetap terhadap total } \\
\text { aset }\end{array}$ & $\frac{\text { Total fixed assets }}{\text { Total assets }}$ \\
\hline $\begin{array}{l}\text { Pertumbuhan } \\
\text { (GRASSET) }\end{array}$ & Pertumbuhan aset & $\frac{\text { Asset }_{t}-\text { Asset }_{t-1}}{\text { Asset }_{t-1}} \times 100 \%$ \\
\hline $\begin{array}{l}\text { Profitabilitas } \\
\text { (ROA) }\end{array}$ & Return on Asset & $\frac{\text { Total net income }}{\text { Total assets }}$ \\
\hline $\begin{array}{l}\text { Umur Perusahaan } \\
\text { (A GE) }\end{array}$ & Periode lama perusahaan berdiri & Current year - year firm was established \\
\hline $\begin{array}{l}\text { Rasio Kas } \\
\text { (CASHRATIO) }\end{array}$ & Cash Ratio & $\frac{\text { Cash and cash equivalent }}{\text { Total assets }}$ \\
\hline $\begin{array}{l}\text { Risiko Bisnis } \\
\text { (RISK) }\end{array}$ & Standar deviasi EBIT & $\sigma$ Earning before interest and tax \\
\hline $\begin{array}{l}\text { Peluang Investasi } \\
\text { (CAPEX) }\end{array}$ & Capital expenditure & Capital Expenditure \\
\hline $\begin{array}{l}\text { Non-Debt Tax } \\
\text { Shield (NDTS) }\end{array}$ & $\begin{array}{l}\text { Proporsi beban depresiasi } \\
\text { terhadap total aset }\end{array}$ & $\frac{\text { Depreciation expense }}{\text { Total asset }}$ \\
\hline $\begin{array}{l}\text { Price-earning } \\
\text { Ratio (PER) }\end{array}$ & Price-earning Ratio & $\frac{\text { Closing share price }}{\text { Earning per share }}$ \\
\hline
\end{tabular}

\section{Hasil dan Pe mbahasan}

\section{Statistik Deskriptif}

Data yang digunakan untuk statistik deskriptif merupakan panel data unbalanced. Jumlah observasi adalah 1303 data yang berasal dari 154 perusahaan selama periode 2006-2015. Hal ini bertujuan untuk menjadikan analis is atas statistik deskriptif lebih relevan. Jumlah observasi yang tidak 


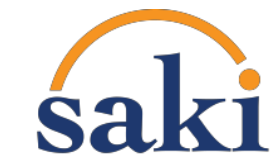

Studi Akuntansi \& Keuangan Indonesia

sesuai disebabkan beberapa perusahaan sampel yang dihilangkan pada tahun tertentu karena tidak tersedianya data perusahaan pada tahun tersebut.

Tabel 4.1 - Statistik Deskriptif

\begin{tabular}{|c|c|c|c|c|c|}
\hline Variabel & Obs & Mean & Std. Dev & Min & Max \\
\hline LEV & 1303 & 42,5905 & 162,1439 & 0 & 4059,42 \\
\hline IO & 1303 & 6,7992 & 9,7432 & 0 & 57,6 \\
\hline Q & 1303 & 1,3841 & 1,7829 & 0,0531 & 17,9418 \\
\hline SIZE & 1303 & 5.042 .219 & 10.670 .544 & 7648,19 & 97.000 .000 \\
\hline LIQ & 1303 & $-0,0768$ & 0,4221 & $-3,3768$ & 2,5446 \\
\hline TANG & 1303 & 0,3739 & 0,2 & 0,0022 & $-0,9838$ \\
\hline ROA & 1303 & 6,2269 & 7,4816 & $-42,4861$ & 54,2363 \\
\hline CAPEX & 1303 & 4,3364 & 1,5033 & 0 & 6,8 \\
\hline $\mathrm{BIG}$ & 1303 & 0,3814 & 0,4859 & 0 & 1 \\
\hline PER & 1303 & 2,0641 & 2,1633 & $-6,0225$ & 8,6159 \\
\hline AGE & 1303 & 36,2809 & 2,1634 & 3 & 198 \\
\hline RISK & 1303 & 1.234 .053 & 430.513 & 532.654 & 1.700 .000 \\
\hline CASHRATIO & 1303 & 0,0909 & 0,1031 & 0,0001 & 0,7014 \\
\hline NDTS & 1303 & 0,0344 & 0,0221 & 0,00002 & 0,1841 \\
\hline GRASSET & 1303 & 0,1983 & 0,9633 & -0.9157 & 22,5597 \\
\hline \multicolumn{6}{|c|}{$\begin{array}{l}\text { LEV adalah struktur modal; IO adalah kepemilikan; Q adalah nilai; SIZE adalah ukuran perusahaan; LIQ adalah likuiditas; TANG } \\
\text { adalah tangibility; ROA adalah profit abilitas; CAPEX adalah peluang investasi; BIG adalah variabel dummy auditor BIG4; PER } \\
\text { adalah rasio price-earning; AGE adalah umur perusahaan; RISK adalah risiko bisnis; CASHRATIO adalah rasio kas; NDT S } \\
\text { adalah non-debt tax shield; GRASSET adalah persentase pertumbuhan aset. }\end{array}$} \\
\hline
\end{tabular}

Variabel utama LEV menunjukan mean $42,59 \%$, yang berarti perusahaan manufaktur di Indonesia cenderung menitikberatkan sumber pendanaannya melalui ekuitas. Nilai minimum 0 merupakan rasio long-term debt to equity perusahaan yang tidak memiliki porsi utang jangka panjang sebagai pendanaan pada tahun yang bersangkutan. Mean dari variabel independen IO adalah 6,79\% dapat diartikan bahwa investor institusional belum menunjukkan minat yang besar untuk berinvestasi dalam perusahaan manufaktur di Indonesia. Keberadaan pemilik institusional belum dapat dideteksi dalam 57 perusahaan manufaktur Indonesia, yang menjelaskan nilai minimum 0 pada variabel IO. Kepemilikan maksimal institusional ditemukan pada perusahaan PT Garuda Metalindo Tbk dengan tingkat kepemilkan institusional 57,6\%. Hal ini menunjukkan adanya sifat controlling investor institusional terhadap perusahaan tersebut lewat kepemilikan saham mayoritas.

Variabel Q merupakan nilai perusahaan yang diukur dengan Tobin's Q. Mean dengan angka 


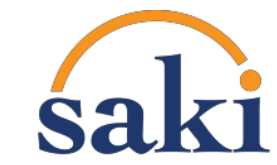

Studi Akuntansi \& Keuangan Indonesia

1,3841 menunjukkan sebagian besar perusahaan memiliki nilai pasar diatas nilai bukunya. Hal ini menandakan bahwa value creation di pasar modal bagi perusahaan-perusahaan manufaktur di Indonesia sudah baik dengan rasio > 1. PT Unilever Indonesia Tbk menunjukkan nilai Q terbesar dari seluruh sampel yaitu sebesar 17,9148. Perusahaan tersebut memiliki nilai pasar jauh diatas nilai buku lewat kemampuan menciptakan value tinggi atas perusahaannya lewat berbagai aspek. Nilai Q minimum 0,05307 ditemukan pada perusahaan PT Resource Alam Indonesia Tbk yang menandakan bahwa perusahaan ini memiliki nilai pasar di bawah nilai bukunya dan mencerminkan reputasi buruk perusahaan.

\section{Uji Hipotesis}

Model Penelitian 1 Untuk Pengujian Pengaruh IO dan LEV terhadap $Q$

Tabel 4.2 - Hasil Uji Hipotesis Model 1

\begin{tabular}{|c|c|c|}
\hline \multicolumn{2}{|c|}{ Prob > F } & 0,0000 \\
\hline \multicolumn{2}{|c|}{ Adjusted R-squared } & 0,2999 \\
\hline \multicolumn{2}{|c|}{ Root MSE } & $\mathbf{0 , 2 8 0 1}$ \\
\hline \multicolumn{3}{|c|}{ Variabel De penden: Q } \\
\hline Variabel Independen & Koefisien & $\mathbf{P}>|\mathbf{t}|$ \\
\hline LEV & 0,0332 & $0,017 * *$ \\
\hline $\mathrm{IO}$ & 0,1765 & $0,022 * *$ \\
\hline SIZE & 0,0188 & $0,000 * * *$ \\
\hline ROA & 21,773 & $0,000 * * *$ \\
\hline CAPEX & 21,768 & $0,000 * * *$ \\
\hline BIG & 0,0498 & $0,006 * * *$ \\
\hline PER & $-0,2212$ & $0,004 * * *$ \\
\hline Konstanta & $-0,0249$ & $0,043^{* *}$ \\
\hline
\end{tabular}

Model pene litian 1 diuji dengan model regresi Pooled OLS dengan variabel dependen Q dan variabel independen LEV, IO, SIZE, ROA, CAPEX, BIG, dan PER. Hasil pengolahan data menunjukkan tingkat adjusted R-square sebesar 29,99\%, dapat diartikan bahwa variabel-variabel independen yang digunakan dalam penelitian dapat menjelaskan variabel dependen dengan tingkat yang baik.

Dengan variabel dependen $\mathrm{Q}, \mathrm{LEV}$ sebagai variabel independen utama pada $\mathrm{H} 3$ berpengaruh 


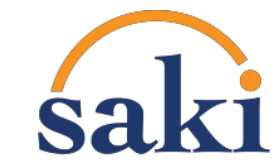

Studi Akuntansi \& Keuangan Indonesia

signifikan positif dengan p-value sebesar 1,7\%**. Hal ini sesuai dengan prediksi awal penelitian yaitu H3. IO sebagai variabel utama untuk H1 juga menunjukkan hasil signifikan 2,2\%** positif yang sesuai dengan hipotesis awal penelitian. Sela in kedua variabel independen utama, terdapat 5 variabel kontrol diikutsertakan dalam regresi yang semuanya berpengaruh secara signifikan terhadap Q. SIZE menunjukkan koefisien negatif sedangkan ROA, CAPEX, BIG dan PER menunjukkan pengaruh positif.

Model Penelitian 2 untuk Pengukuran Pengaruh IO terhadap LEV

Tabel 4.3 - Hasil Uji Hipotesis Model 2

\begin{tabular}{|c|c|c|}
\hline \multicolumn{2}{|c|}{ Prob $>$ F } & 0,0000 \\
\hline \multicolumn{2}{|c|}{ Adjusted R-s quared } & $\mathbf{0 , 1 3 1 0}$ \\
\hline \multicolumn{2}{|c|}{ Root MSE } & $\mathbf{0 , 5 0 3 3}$ \\
\hline \multicolumn{3}{|c|}{ Variabel Dependen: LEV } \\
\hline Variabel Independen & Koefisien & $P>|t|$ \\
\hline IO & $-0,1658$ & $0,079 * *$ \\
\hline SIZE & 0,0447 & $0,000 * * *$ \\
\hline LIQ & $-0,0044$ & 0,907 \\
\hline TANG & 0,1466 & $0,014 * *$ \\
\hline $\mathrm{AGE}$ & $-0,0012$ & $0,004 * * *$ \\
\hline RISK & 186,051 & $0,001 * * *$ \\
\hline CASHRATIO & $-10,450$ & $0,000 * * *$ \\
\hline NDTS & 0,9933 & 0,319 \\
\hline GRA SSET & 0,08665 & $0,000 * * *$ \\
\hline Konstanta & $-0,0528$ & $0,004 * * *$ \\
\hline $\begin{array}{l}\text { IO adalah kepemilikan institusional; } \\
\text { adalah umur perusahaan; RISK adal } \\
\text { GRASSET adalah persentase pertumb } \\
* * * * \text { menandakan tingkat signifikansi } 1 \\
\end{array}$ & $\begin{array}{r}\text { ran perusahaan; LIQ adalah } 1 \\
\text { CASHRAT IO adalah rasio } \\
\text { cantingkat signifikansi } 5 \% \text {; }\end{array}$ & $\begin{array}{l}\text { adalah tangibility; AGE } \\
\text { ah non-debt tax shield; } \\
\text { at signifikansi } 1 \% \text {. }\end{array}$ \\
\hline
\end{tabular}

Pada model 2 seperti yang tergambar di tabe14.3, nilai koefisien determinasi berganda senilai 13,1\% yang menjelaskan bahwa variabel independen secara kesuluruhan mempengaruhi variabel dependen sebanyak 13,1\%. Variabel-variabel independen mempengaruhi variabel dependen secara bervariasi. IO mempengaruhi LEV dengan nilai p-value 7,9\%* dan memiliki koefis ien negatif, yang menandakan IO mempengaruhi LEV secara negatif. Hasil regresi menunjukkan hasil sesuai dengan hipotesis awal yang diajukan untuk $\mathrm{H} 2$.

SIZE mempengaruhi LEV secara positif. LIQ tidak berpengaruh signifikan terhadap LEV dengan angka p-value 90,7\%. Variabel TANG memiliki angka p-value 1,14\%** sehingga 
mempengaruhi secara signifikan dan memiliki pengaruh positif. Ketiga variabel AGE, RISK, dan CASHRATIO berpengaruh signifikan dan ketiganya memiliki pengaruh negatif terhadap LEV. NDTS tidak berpengaruh signifikan terhadap LEV dan GRASSET berpengaruh sigifikan secara positif.

\section{Pembahasan}

Pengaruh Kepemilikan Institusional terhadap Nilai Perusahaan

Hasil regresi kepemilikan institusional terhadap nilai perusahaan sesuai dengan hipotesis penelitian H1 dan konsisten dengan penelitian McConnell dan Servaes (1990), Chaganti dan Damanpour (1991), Han dan Suk (1992), Lins (2013), dan Jafarinejad et al. (2015). Menurut Crutchley et al. (1999), salah satu wujud kontrol berasal dari monitoring yang dilakukan oleh mutual funds dan dana pensiun atau disebut juga pihak institusional. Pemegang saham institusional biasanya memiliki proporsi saham dalam jumlah besar di perusahaan (Gillan dan Starks, 2008 dan Tarjo, 2008). Oleh sebab itu, sulit bagi investor institusional untuk menjual proporsi sahamnya dan lebih memilih untuk melakukan monitoring yang efektif untuk mempertahankan performa sahamnya (Crutchley et al., 1999).

Hubungan antara pemegang saham sebagai principle dan manajemen sebagai agen akan menimbulkan konflik kepentingan, yaitu dimana manajemen tidak selalu bertindak sesuai dengan tujuan pemegang saham yaitu memaksima kan nilai perusahaan (Jensen dan Meckling, 1976). Dengan demikian, agency problem akan muncul dan menimbulkan agency cost yang dapat mempengaruhi nilai perusahaan menurut teori agensi. Dengan adanya monitoring yang efektif dari investor institusional (Shleifer dan Vishny, 1986) dan kuasa atas keputusan manajemen, manajemen perusahaan akan mendapatkan tekanan untuk beradaptasi untuk menjalankan kehendak dari principle yang berkaitan dengan kinerja perusahaan dan menciptakan strategi yang sesuai dengan tujuan investor institusional (Chaganti dan Damanpour, 1991). Dengan demikian, agency problem akan terminimalisir (Crutchley et al., 1999), meminimalkan agency cost, dan menaikkan nilai perusahaan. Hal tersebut sesuai dengan hipotesis dan hasil regresi penelitian bahwa kepemilikan institusional mempengaruhi nilai perusahaan secara positif.

Negara berkembang umumnya berkaitan dengan tingkat proteksi terhadap pemegang saham 
yang rendah (Lins, 2003). Hasil penelitian Lins (2003) mengenai struktur kepemilikan saham terhadap nilai perusahaan di negara berkembang mengatakan bahwa pemegang saham blok nonmanajerial, salah satunya merupakan kepemilikan institusional, mempengaruhi nilai perusahaan secara positif di negara yang memiliki tingkat proteksi terhadap pemegang saham yang rendah. Hal ini dikarenakan kontrol yang dilakukan oleh pemegang saham blok non-manajerial merupakan substitusi dari mekanisme tata kelola yang hilang karena rendahnya tingkat proteksi terhadap pemegang saham. Indonesia merupakan salah satu negara berkembang. Maka sesuai dengan hasil penelitian Lins (2003) bahwa kepemilikan institus ional mempengaruhi positif nilai perusahaan.

\section{Pengaruh Kepemilikan Institusional terhadap Struktur Modal}

Berdasarkan hasil regresi Pooled OLS, kepemilikan institusional mempengaruhi struktur modal secara negatif, konsisten dengan hasil penelitian Chaganti dan Damanpour (1991) dan Michaely dan Vincent (2013). Menurut teori Pecking Order (Myers dan Majluf, 1984), perusahaan memiliki urutan pilihan pendanaan yaitu mendahulukan pendanaan internal dibandingkan utang dan mendahulukan utang dibandingkan ekuitas. Hal ini disebabkan adanya information cost atau biaya untuk mengedukasi dan menyediakan informasi bagi investor yang meningkat seiring dengan prioritas pilihan pendanaan perusahaan. Investor institusional menggunakan banyak sumber daya untuk mengumpulkan informasi perusahaan yang mereka investasikan serta menerapkan economies of scale dalam pengumpulan dan memproses informasi perusahaan, sehingga menyebabkan investor institusional lebih memiliki banyak informasi dibandingkan tipe investor lain (Attig et al., 2012; Michaely dan Vincent, 2013). Adanya investor institusional memperkecil asymmetry information yang terjadi antara manajemen dan outside shareholder karena informasi yang mereka peroleh terefleksikan dalam pola trading mereka (Sias, 2004; Bushee dan Godman, 2007). Dengan demikian, investor institusional mengurangi information cost dan menyebabkan perusahaan dengan kepemilikan intitusional tinggi memiliki leverage yang kecil dibandingkan perusahaan dengan kepemilikan institusional rendah.

Tingkat utang pada suatu perusahaan dipengaruhi oleh mekanisme monitoring internal dan eksternal yang bertujuan untuk megontrol tindakan manajemen (Bathala, Moon, \& Rao, 1994). 
Pembagian dividen, utang, dan kepemilikan manajerial merupakan wujud kontrol internal yang dilakukan oleh perusahaan (Crutchley et al., 1999), sedangkan investor institus ional merupakan pihak yang berperan secara signifikan sebagai kontrol eksternal lewat pasar modal (Agrawal dan Mandelker, 1990). Berangkat dari uraian di atas, pembahasan atas pengaruh kepemilikan institusional terhadap struktur modal juga dapat di assess dengan teori agensi Jensen dan Meckling (1976).

Keputusan pendanaan melalui utang juga berfungsi sebagai kontrol internal, bertujuan untuk mengurangi agency problem dengan mengikat perusahaan pada pembayaran bunga secara berkala (Jensen, 1986). Kepemilikan institusional juga dapat mengurangi agency problem dengan me lakukan monitoring. Oleh sebab itu, adanya investor institusional menyebabkan manajemen mengurangi wujud kontrol internalnya yang memakan biaya (Crutchley et al., 1999) dan menjadikan investor institusional sebagai substitusi utang sebagai peran yang menjalankan kontrol (Jensen, 1986) dalam mengurangi agency problem.

Saat investor institusional memegang porsi yang besar dalam perusahaan, corporate governance perusahaan akan meningkat (Chung dan Zhang, 2011) dan dapat menggantikan peran controlling dari utang. Monitoring yang efektif oleh pemilik institusional ini secara keseluruhan memitigasi masalah asymmetry information dan konflik agensi (Attig et al., 2012) serta mendorong manajemen untuk mengurangi utang untuk mengantisipasi adanya risiko kebangkrutan (Crutchley et al., 1999).

Natapura (2007) melakukan analisis mengenai perilaku investor institusional di Indonesia dengan hasil yang serupa dengan pandangan Michaely dan Vincent (2013), bahwa investor institusional cenderung berusaha mengumpulkan informasi sebanyak-banyaknya, selalu menganalisis informasi yang diperoleh, melakukan investasi jangka panjang, dan berusaha untuk meminimalkan risiko yang dihadapi.

Dengan demikian, dapat disimpulkan bahwa investor institusional di Indonesia akan meminimalkan information cost dan pada akhirnya menyebabkan perusahaan dengan kepemilikan institusional besar memilih leverage kecil, serta mendorong manajemen untuk mengurangi utang untuk menghindari risiko financial distress. 


\section{Pengaruh Struktur Modal terhadap Nilai Perusahaan}

Hasil regresi struktur modal terhadap nilai perusahaan menunjukkan adanya pengaruh positif struktur modal terhadap nilai perusahaan, sesuai dengan hipotesis penelitian (H3). Hasil penelitian mengenai kedua variabel konsisten dengan hasil penelitian Margaritis dan Psillaki (2010), Zeitun dan Tian (2014), Hasbi (2015), dan Hermuningsih (2015).

Teori agensi mengemukakan bahwa nilai perusahaan akan meningkat saat agency cost dapat diatasi, salah satunya dengan kontrol yang baik (Jensen dan Meckling, 1976). Kepemilikan institusional merupakan salah satu bentuk kontrol yang efisien baik (Grossman dan Hart, 1980; Shleifer and Vishny, 1986; Attig et al., 2012), dimana utang merupakan subsitusi atas bentuk kontrol tersebut. Friend dan Lang (1988) menyatakan keputusan pendanaan perusahaan untuk menaikkan jumlah utang konsisten dengan penurunan agency cost.

Jensen (1986) menyatakan bahwa adanya utang yang mengikat perusahaan untuk melakukan pembayaran pokok dan bunga secara periodik dapat mengurangi penyalahgunaan manajemen atas arus kas bebas untuk menjalani proyek yang tidak menguntungkan bagi perusahaan. Utang juga memberikan tekanan kepada manajemen untuk bekerja dengan lebih efisien guna menghindari adanya risiko jatuhnya reputasi perusahaan bahkan ancaman likuidasi perusahaan jika tidak berhasil memenuhi kewajiban pembayaran utangnya (Grossman dan Hart, 1982). Dengan demikian, utang dapat mengurangi agency cost dan meningkatkan nilai perusahaan (Bathala et al., 1994).

Selain utang tersebut sendiri menjadi kontrol bagi perusahaan, utang dapat memicu kontrol dari kreditur yang bersangkutan. Hal ini turut serta mengatasi agency problem yang terjadi antara principle dan manajemen serta agency cost terkait (Agrawal and Knoeber, 1996). Utang juga merupakan salah satu bentuk corporate governance dalam perusahaan (Mulyani et al., 2016), dimana corporate governance tersebut dapat meningkatkan nilai perusahaan (Klapper dan Love, 2004; Cheung et al., 2007).

\section{Variabel Kontrol terhadap Nilai Perusahaan}

Selain variabel independen struktur modal dan kepemilikan institusional, variabel-variabel lain juga mempengaruhi nilai perusahaan pada penelitian ini. Ukuran perusahaan berpengaruh negatif dikarenakan manajemen yang berada di perusahaan yang berukuran besar cenderung melakukan 
tindakan oportunistik dan mengabaikan performa perusahaan (Pervan dan Visic, 2012). Profitabilitas berpengaruh positif terhadap nilai perusahaan dan konsisten dengan penelitian terdahulu (Margaritis dan Psillaki, 2010; Al-Najjar dan Taylor, 2008). Peluang investasi berpengaruh positif terhadap nilai perusahaan. Auditor BIG4 memiliki pengaruh positif terhadap nilai perusahaan dikarenakan adanya perspektif dari investor bahwa auditor BIG4 adalah salah satu faktor yang menaikkan nilai perusahaan, konsisten dengan penelitian Wang dan Huang (2014).

\section{Variabel Kontrol terhadap Struktur Modal}

Penelitian ini mengikutsertakan 8 variabel kontrol yang ikut mempengaruhi variabel dependen struktur modal. Ukuran perusahaan sesuai prediksi memiliki pengaruh positif terhadap struktur modal, konsisten dengan hasil penelitian Margaritis dan Psillaki (2010). Semakin besar perusahaan, risiko kebangkrutan yang dihadapi akan semakin kecil sehingga perusahaan mendapatkan akses untuk kredit. Konsisten dengan penelitian Titman dan Wessels (1998), variabel tangibility berpengaruh positif dikarenakan faktor banyaknya jaminan aset tetap yang dapat dijadikan jaminan untuk mendapatkan pendanaan secara utang dari bank. Pertumbuhan berpengaruh positif terhadap struktur modal, konsisten dengan penelitian Hasbi (2015) dan Hemurnings ih (2013). Perusahaan yang sedang bertumbuh cenderung menambah utangnya untuk melakukan investasi. Umur perusahaan berpengaruh negatif terhadap struktur modal dikarenakan perusahaan memiliki manajemen cash flow yang baik sehingga memerlukan utang yang lebih sedikit. Risiko Bisnis mempengaruhi secara negatif dikarenakan utang menuntut adanya pembayaran secara periodik (Guha-Khasnobis dan Bhaduri, 2002), sehingga perusahaan yang kurang stabil cenderung tidak memilih utang sebagai sumber pendanaannya.

Rasio kas berpengaruh negatif terhadap struktur modal sesuai penelitian Mulyani et al. (2016) dikarenakan kas meningkatkan rasio payout dividen yang merupakan wujud kontrol selain utang (Crutchley et al., 1999), sehingga dapat digunakan sebagai substitusi utang.

\section{Kesimpulan, Implikasi, dan Keterbatasan}

Penelitian ini meneliti pengaruh kepemilikan institusional terhadap nilai perusahaan dan struktur modal, serta pengaruh struktur modal terhadap nilai perusahaan. Berdasarkan hasil regresi 
Pooled OLS, kepemilikan institusional terhadap nilai perusahaan bahwa terdapat pengaruh positif karena monitoring oleh pemilik institusional yang efektif terhadap tindakan manajemen, sehingga menekan konflik agensi dan menaikkan nilai perusahaan. Kepemilikan institusional secara signifikan mempengaruhi struktur modal secara negatif dikarenakan kehadiran investor institusional meminimalisir information gap antara manajemen dengan outside shareholder dan menjadi substitusi atas sifat controlling dari utang. Struktur modal mempengaruhi nilai perusahaan secara positif dikarenakan utang sebagai substitusi kepemilikan institusional dalam hal kontrol berperan dalam menurunkan agency cost yang turut serta meningkatkan nilai perusahaan.

Bagi perusahaan, hasil penelitian dapat menjadi salah satu sumber informasi untuk pengambilan keputusan mengenai struktur kepemilikan saham dan struktur modal yang sesuai bagi masing-masing perusahaan. Untuk mencapai nilai perusahaan yang maksimal, perusahaan dapat mempertimbangkan pendanaan secara utang sebagai subsitusi jika tidak ada porsi saham yang dimiliki oleh investor institusional. Penelitian ini juga dapat menjadi salah satu acuan untuk pengambilan keputusan dalam investasi bagi para investor yang ingin berinvestasi pada perusahaan manufaktur di Indonesia. Investor yang aktif dalam kegiatan trading cenderung menghadapi berbagai constraint serta mempertimbangkan trade off yang tidak seimbang antara informasi yang didapatkan dan keuntungan bagi investor tersebut. Penelitian ini menyediakan inisght bagi investor, bahwa pola trading investor institusional merupakan dasar keputusan investasi yang baik.

Penelitian ini tentunya tidak luput dari keterbatasan. Pada penelitian ini, kepemilikan institusional belum diuraikan menjadi pressure-sensitive, yaitu investor yang memiliki hubungan bisnis dengan perusahaan tempat berinvestasi, dan pressure-resistant, yaitu investor yang tidak memiliki hubungan bisnis dengan perusahaan tempat berinvestasi. Hal ini tidak dapat dilakukan pada penelitian ini karena penulis tidak memiliki akses untuk memperoleh data tersebut. Penelitian selanjutnya diharapkan dapat menganalisis lebih dalam mengenai jenis-jenis kepemilikan institusional. 


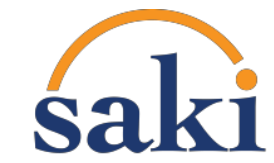

Studi Akuntansi \& Keuangan Indonesia

\section{Daftar Pustaka}

Agrawal, A., \& Knoeber, C. R. (1996). Firm Performance and Mechanisms to Control Agency Problems between Managers and Shareholders. The Journal of Financial and Quantitative Analysis, 31(3), 377-397. https://doi.org/10.2307/2331397

Agrawal, A., \& Mandelker, G. N. (1990). Large Shareholders and the Monitoring of Managers: The Case of Antitakeover Charter A mendments. The Journal of Financial and Quantitative Analysis, 25(2), 143161. https://doi.org/10.2307/2330821

Al-Najjar, B. (2010). Corporate governance and institutional ownership: evidence from Jordan. Corporate Governance: The international journal of business in society, 10(2), 176-190. https://doi.org/10.1108/14720701011035693

Al-Najjar, B., \& Taylor, P. (2008). The relationship between capital structure and ownership structure: New evidence from Jordanian panel data. Managerial Finance, 34(12), 919-933. https://doi.org/10.1108/03074350810915851

Al-Saidi, M., \& Al-Shammari, B. (2015). Ownership concentration, ownership composition and the performance of the Kuwaiti listed non-financial firms. International Journal of Commerce and Management, 25(1), 108-132. https://doi.org/10.1108/IJCOMA-07-2013-0065

Ashrafi, M. (2015). A Cubic Relationship between Institutional Ownership and Capital Structure - ProQuest. http://search.proquest.com/openview/43d3e994bc77a0518250252969eee0dc/1?pqorigsite $=$ gscholar\&cbl $=2032294$

Attig, N., Cleary, S., El Ghoul, S., \& Guedhami, O. (2012). Institutional investment horizon and investmentcash flow sensitivity. Journal of Banking \& Finance, 36(4), 1164-1180. https://doi.org/10.1016/j.jbankfin.2011.11.015

Bathala, C. T., Moon, K. P., \& Rao, R. P. (1994). Managerial Ownership, Debt Policy, and the Impact of Institutional Holdings: An Agency Perspective. Financial Management, 23(3), 38-50. https://doi.org/10.2307/3665620

Berger, A. N., \& Bonaccorsi di Patti, E. (2006). Capital structure and firm performance: A new approach to testing agency theory and an application to the banking industry. Journal of Banking \& Finance, 30(4), 1065-1102. https://doi.org/10.1016/j.jbankfin.2005.05.015

Bhattacharya, P. S., \& Graham, M. A. (2009). On institutional ownership and firm performance: A disaggregated view. Journal of Multinational Financial Management, 19(5), 370-394. https://doi.org/10.1016/j.mulfin.2009.07.004

Bhojraj, S., \& Sengupta, P. (2003). Effect of Corporate Governance on Bond Ratings and Yields: The Role of Institutional Investors and Outside Directors. The Journal of Business, 76(3), 455-475. https://doi.org/10.1086/344114

Bushee, B. J., \& Goodman, T. H. (2007). Which Institutional Investors Trade Based on Private Information About Earnings and Returns? Journal of Accounting Research, 45(2), 289-321. https://doi.org/10.1111/j.1475-679X.2007.00234.x

Chaganti, R., \& Damanpour, F. (1991). Institutional Ownership, Capital Structure, and Firm Performance. Strategic Management Journal, 12(7), 479-491.

Cheung, Y.-L., Thomas Connelly, J., Limpaphayom, P., \& Zhou, L. (2007). Do Investors Really Value Corporate Governance? Evidence from the Hong Kong Market. Journal of International Financial Management \& Accounting, 18(2), 86-122. https://doi.org/10.1111/j.1467-646X.2007.01009.x

Chung, K. H., \& Zhang, H. (2011). Corporate Governance and Institutional Ownership. The Journal of Financial and Quantitative Analysis, 46(1), 247-273.

Crutchley, C. E., Jensen, M. R. H., Jahera, J. S., \& Raymond, J. E. (1999). Agency problems and the simu ltaneity of financial decision making. International Review of Financial Analysis, 8(2), 177-197. https://doi.org/10.1016/S1057-5219(99)00011-3

Firth, M. (1995). The Impact of Institutional Stockholders and Managerial Interests on the Capital Structure of Firms. Managerial and Decision Economics, 16(2), 167-175.

Friend, I., \& Lang, L. H. P. (1988). An Empirical Test of the Impact of Managerial Self-Interest on Corporate Capital Structure. The Journal of Finance, 43(2), 271-281. https://doi.org/10.2307/2328459

Gillan, S. L., \& Starks, L. T. (2000). Corporate governance proposals and shareholder activism: the role of institutional investors. Journal of Financial Economics, 57(2), 275-305. https://doi.org/10.1016/S0304-405X(00)00058-1

Gregory, A., \& Wang, Y. (2013). Cash acquirers: Can free cash flow, debt and institutional ownership exp lain long-run performance? Review of Behavioral Finance, 5(1), 35-57. https ://doi.org/10.1108/RBF-022013-0010

Grossman, S. J., \& Hart, O. D. (1983). Corporate Financial Structure and Managerial Incentives (Working Paper No. 398). National Bureau of Economic Research. http://www.nber.org/papers/r0398 


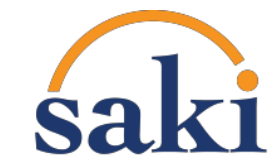

Studi Akuntansi \& Keuangan Indonesia

Grossman, S. J., \& Hart, O. D. (1986). The Costs and Benefits of Ownership: A Theory of Vertical and Lateral Integration. Journal of Political Economy, 94(4), 691-719.

Guha-Khasnobis, B., \& N. Bhaduri, S. (2002). Determinants of Capital Structure in India (1990-1998): A Dynamic Panel Data Approach. Journal of Economic Integration, 17, 761-776.

Hammerstrom, G. \& Jersov, K. (2014). The effect of Institutional Ownership on the Capital Structure of Swedish Firms. Stockholm School of Econo mics. http://arc.hhs.se/download.aspx?Mediu mId=2319

Han, K. C., \& Suk, D. Y. (1998). The effect of ownership structure on firm performance: Additional evidence. Review of Financial Economics, 7(2), 143-155. https://doi.org/10.1016/S1058-3300(99)80150-5

Hariati, I. \& Rihatiningtyas, Y.W. (2015). Pengaruh Tata Kelola Perusahaan dan Kinerja Lingkungan Terhadap Nilai Perusahaan. Simposium Nasional Akuntansi 18, http://lib.ibs.ac.id/materi/SNA\% 20XVIII/makalah/001.pdf

Hasbi, H. (2015). Islamic Microfinance Institution: The Capital Structure, Growth, Performance and Value of Firm in Indonesia. Procedia - Social and Behavioral Sciences, 211, 1073-1080. https://doi.org/10.1016/j.sbspro.2015.11.143

Hermuningsih, S. (2014). Pengaruh Profitabilitas, Growth Opportunity, Struktur Modal Terhadap Nilai Perusahaan Pada Perusahaan Publik Di Indonesia. Bulletin of Monetary Economics and Banking (Buletin Ekonomi Moneter dan Perbankan), 16(2), 127-148. https://doi.org/10.21098/bemp.v16i2.27

Hillman, A. J., \& Dalziel, T. (2003). Boards of Directors and Firm Performance: Integrating Agency and Resource Dependence Perspectives. The Academy of Management Review, 28(3), 383-396. https://doi.org/10.2307/30040728

Jafarinejad, M., Jory, S. R., \& Ngo, T. N. (2015). The effects of institutional ownership on the value and risk of diversified firms. International Review of Financial Analysis, 40, 207-219. https://doi.org/10.1016/j.irfa.2015.05.019

Jensen, M. C. (1986). Agency Costs of Free Cash Flow, Corporate Finance, and Takeovers. The American Economic Review, 76(2), 323-329.

Jensen, M. C., \& Meckling, W. H. (1976). Theory of the firm: Managerial behavior, agency costs and ownership structure. Journal of Financial Economics, 3(4), 305-360. https://doi.org/10.1016/0304405X(76) $90026-\mathrm{X}$

Klapper, L. F., \& Love, I. (2004). Corporate governance, investor protection, and performance in emerg ing markets. Journal of Corporate Finance, 10(5), 703-728. https://doi.org/10.1016/S09291199(03)00046-4

Lee, S. (2008). Ownership Structure and Financial Performance: Evidence from Panel Data of South Korea (Working Paper Series, Department of Economics, University of Utah No. 2008_17). University of Utah, Department of Economics. https://ideas.repec.org/p/uta/papers/2008_17.html

Lins, K. V. (2003). Equity Ownership and Firm Value in Emerging Markets. The Journal of Financial and Quantitative Analysis, 38(1), 159-184. https://doi.org/10.2307/4126768

Margaritis, D., \& Psillaki, M. (2010). Capital structure, equity ownership and firm performance. Journal of Banking \& Finance, 34(3), 621-632. https://doi.org/10.1016/j.jbankfin.2009.08.023

McConnell, J. J., \& Servaes, H. (1990). Additional evidence on equity ownership and corporate value. Journal of Financial Economics, 27(2), 595-612. https ://doi.org/10.1016/0304-405X(90)90069-C

Michaely, R., \& Vincent, C. J. (2012). Do Institutional Investors Influence Capital Structure Decisions? https://www.researchgate.net/publication/315429108 Do Institutional Investors Influence Capital Structure Decisions

Morck, R., Nakamura, M., \& Shivdasani, A. (2000). Banks, Ownership Structure, and Firm Value in Japan. The Journal of Business, 73(4), 539-567. https://doi.org/10.1086/209654

Mulyani, E., Singh, H., \& Mishra, S. (2016). Dividends, leverage, and family ownership in the emerg ing Indonesian market. Journal of International Financial Markets, Institutions and Money, 43, 16-29. https://doi.org/10.1016/j.intfin.2016.03.004

Myers, S. C. (1977). Determinants of corporate borrowing. Journal of Financial Economics, 5(2), 147-175. https://doi.org/10.1016/0304-405X(77)90015-0

Myers, S. C., \& Majluf, N. S. (1984). Corporate financing and investment decisions when firms have information that investors do not have. Journal of Financial Economics, 13(2), 187-221. https://doi.org/10.1016/0304-405X(84)90023-0

Natapura, C. Analisis Perilaku Investor Institusional dengan Pendekatan Analytical Hierarchy Process (AHP). Jurnal Ilmu Administrasi dan Organisasi, 180 18), http://journal.ui.ac.id/inde x.php/jbb/article/viewFile/620/605

Navissi, F., \& Naiker, V. (2006). Institutional ownership and corporate value. Managerial Finance, 32(3), 247256. https://doi.org/10.1108/03074350610646753

Pervan, M. and Visic, J. (2012) Influence of Firm Size on Its Business Success. Croatian Operational Research Review

(CRORR),

3 ,

213-223. 


\section{saki}

Studi Akuntansi \& Keuangan Indonesia

http://jfbmnet.com/journals/jfb m/Vol_2_No_3_4_December_2014/3.pdf

Pirzada, K., Mustapha, M. Z. B., \& Wickramasinghe, D. (2015). Firm Performance, Institutional Ownership and Capital Structure: A Case of Malaysia. Procedia - Social and Behavioral Sciences, 211, 170-176. https://doi.org/10.1016/j.sbspro.2015.11.025

Setianto, B. (2016). Mengungkap Strategi Investor Institusi Sebagai penggerak utama kenaikan harga saham. BSK Capital.

Shleifer, A., \& Vishny, R. W. (1986). Large Shareholders and Corporate Control. Journal of Political Economy, 94(3), 461-488.

Sias, R. W. (2004). Institutional Herding. The Review of Financial Studies, 17(1), 165-206.

Soumadi, M. M., \& Hayajneh, O. S. (2012). Capital Structure and Corporate Performance Empirical Study on The Public Jordanian Shareholdings Firms Listed in The Amman Stock Market. European Scientific Journal, ESJ, 8(22). http://eujournal.org/index.php/esj/article/view/426

Sundaramurthy, C., Rhoades, D. L., \& Rechner, P. L. (2005). A Meta-analysis of the Effects of Executive and Institutional Ownership on Firm Performance. Journal of Managerial Issues, 17(4), 494-510.

Tarjo. 2008. Pengaruh Konsentrasi Kepemilikan Institusional dan Leverage terhadap Manajemen Laba, Nilai Pemegang Saham, serta Cost of Equity Capital. Simposium Nasional Akuntansi XI Pontianak.

Titman, S., \& Wessels, R. (1988). The Determinants of Capital Structure Choice. The Journal of Finance, 43(1), 1-19. https://doi.org/10.1111/j.1540-6261.1988.tb02585.x

Vo, X. V., \& Ellis, C. (n.d.). An empirical investigation of capital structure and firm value in Vietnam. Finance Research Letters. https://doi.org/10.1016/j.frl.2016.10.014

Wang, Y.-F., \& Huang, Y.-T. (2014). How Do Auditors Increase Substantially Firm Value? International Journal of Economics and Finance, 6(10), 76. https://doi.org/10.5539/ijef.v6n10p76

Wei, Z., Xie, F., \& Zhang, S. (2005). Ownership Structure and Firm Value in China's Privatized Firms: 19912001. The Journal of Financial and Quantitative Analysis, 40(1), 87-108.

Zeitun, R., \& Tian, G. G. (2007). Capital Structure and Corporate Performance: Evidence from Jordan'. https://www.researchgate.net/publication/30384561_Capital_Structure_and_Corporate_Performance_ Evidence_from_Jordan' 